\title{
Inhibition of Tumor Cell Growth by Interferon- $\gamma$ Is Mediated by Two Distinct Mechanisms Dependent upon Oxygen Tension: Induction of Tryptophan Degradation and Depletion of Intracellular Nicotinamide Adenine Dinucleotide
}

\author{
Thomas M. Aune and Sarah L. Pogue \\ Department of Molecular Immunology, Genentech, Inc., South San Francisco, California 94080
}

\begin{abstract}
Growth of a variety of human tumor cell lines is inhibited by interferon- $\gamma($ IFN- $\gamma)$ in vitro. This mechanism is not well understood. The present experiments identify two separate mechanisms which account for the growth inhibitory activity of IFN- $\gamma$. Cell lines most sensitive to IFN- $\gamma$ (inhibited by 10-30 $\mathrm{U} / \mathrm{ml}$ IFN- $\gamma$ in 3 d) were stimulated by IFN- $\gamma$ to oxidize tryptophan in media to kynurenine and completely eliminated tryptophan from the culture media after 48-72 h. Addition of L-tryptophan, but not other aromatic amino acids, other essential amino acids, or D-tryptophan, prevented inhibition of cell growth by IFN- $\gamma$. The amount of IFN- $\gamma$ required to yield $50 \%$ inhibition of cell growth was directly related to the concentration of L-tryptophan in culture media and increased from $\sim \mathbf{3}$ to $600 \mathrm{U} / \mathrm{ml}$ as the concentration of tryptophan in the media was increased from 25 to $1,000 \mu \mathrm{M}$. By contrast, inhibition of growth of the cell lines, BT20 and HT29, was not prevented by addition of tryptophan. Inhibition by IFN- $\gamma(100-300 \mathrm{U} / \mathrm{ml}$ after 5-6 d) was, however, completely prevented by addition of two inhibitors of adenosine diphosphate-ribosyl transferase (ADP-RT), 3-aminobenzamide or nicotinamide. Activity of ADP-RT was increased in these cell lines after addition of IFN- $\boldsymbol{\gamma}$. ADP-RT catalyzes the incorporation of the ADP moiety of nicotinamide adenine dinucleotide (NAD) into proteins and causes depletion of intracellular NAD. All tumor cell lines tested had reduced levels of intracellular NAD after treatment with IFN- $\gamma$ and loss of NAD preceded inhibition of cell growth by 12-24 h. Inhibitors of IFN- $\gamma$-mediated inhibition of cell growth prevented loss of levels of intracellular NAD. Generation of reactive oxygen species lead to DNA strand breaks which result in activation of ADP-RT. Increased DNA strand breaks were induced in BT20 and HT29 cells but not ME180 and A549 cells after culture with IFN- $\gamma$. The two enzymes known to catalyze the decyclization of tryptophan to kynurenine require superoxide anion for activity. Increased amounts of superoxide anion were released from ME180 and A549 cells after culture with IFN- $\gamma$. Reduced oxygen concentration decreased the ability of IFN- $\gamma$ to inhibit tumor cell growth in vitro. Intracellular glutathione has been shown to protect cells against oxidative damage by various agents. Elevation or reduction of intracellular glutathione concentrations
\end{abstract}

Address reprint requests to Dr. Aune at his present address: Miles Research Center, 400 Morgan Lane; West Haven, CT 06516.

Received for publication 12 May 1988 and in revised form 28 April 1989.

J. Clin. Invest.

(c) The American Society for Clinical Investigation, Inc. 0021-9738/89/09/0863/13 \$2.00

Volume 84, September 1989, 863-875 lowered or raised sensitivity of cell lines to IFN- $\gamma$, respectively. These data indicate that at least two distinct mechanisms can account for IFN- $\boldsymbol{\gamma}$-mediated inhibition of tumor cell growth. Both mechanisms appear to be sensitive to oxygen tension and to changes in intracellular glutathione concentrations, and both mechanisms lead to loss of intracellular NAD.

\section{Introduction}

Interferons represent a class of proteins with various biological properties $(1,2)$. These include the ability to inhibit intracellular replication of viruses and certain parasites (3), the ability to inhibit replication of certain types of tumor cells in vitro (4), and the ability to modulate immune responses in vitro and in vivo in a positive or negative manner (2). The various activities of interferons have been suggested to be associated with changes in the expression of certain genes and proteins such as double-stranded RNA-dependent protein kinases, 2',5'-oligoadenylate synthetase, ribonuclease $L$, or certain oncogene mRNAs (5). Additionally, interferons have been shown to alter intracellular concentrations of cyclic $3^{\prime}, 5^{\prime}$ adenosine monophosphate, phosphorylation of ribosome-associated proteins and intracellular cytoskeletal structure (6).

Of the interferons, interferon- $\gamma($ IFN- $\gamma)$ is thought to be a more effective immunomodulatory agent and a more effective inhibitor of division of certain tumor cells in vitro than other interferons $(2,4)$. The response of human tumor cell lines to IFN- $\gamma$ is heterogeneous. Some tumor cell lines are relatively sensitive to growth inhibition by IFN- $\gamma$ whereas others are less sensitive and some cell lines are totally resistant. Further, the activity of IFN- $\gamma$ against growth of tumor cell lines in vivo is not as great as the activity which has been observed in vitro (7). Unifying mechanisms are not available to explain these apparent differences. Recent data have emerged to suggest that one mechanism of IFN- $\gamma$-mediated growth inhibition is the stimulation of cellular oxidation of tryptophan by indoleamine 2,3dioxygenase $(8,9)$. However, certain other tumor cell lines growth inhibited by IFN- $\gamma$ do not increase tryptophan catabo$\operatorname{lism}(9,10)$.

One possible difference which could influence the response of tumor cells to IFN- $\gamma$ in vitro or in vivo is the oxygen tension. Solid tumors in vivo exist in significantly lower oxygen tension than found in monolayers of cells in tissue culture (11). Results presented here demonstrate that: $(a)$ reduced oxygen tension reduces the antiproliferative activity of IFN- $\gamma$ in vitro; $(b)$ increases or decreases in intracellular glutathione concentration decrease or increase, respectively, sensitivity of tumor cell lines to growth inhibition by IFN- $\gamma$, and (c) two distinct mechanisms have been identified which account for the inhibitory activity of IFN- $\gamma$ against several different tumor cell lines. One mechanism is stimulation of cellular catabolism of tryptophan, and the second is stimulation of cellular catabo- 
lism of nicotinamide adenine dinucleotide (NAD) by adenosine diphosphate-ribosyl transferase (ADP-RT) ${ }^{1}$ (12). Two enzymes known to catabolize tryptophan are tryptophan 2,3dioxygenase and indoleamine 2,3-dioxygenase (13). Both enzymes require superoxide anion for activity. One mechanism of activation of ADP-RT is through generation of DNA strand breaks. A wide variety of agents capable of producing oxidizing species have been shown to mediate DNA damage by this mechanism (14). These observations may help explain the dependency of IFN- $\gamma$ antiproliferative activity in vitro on oxygen tension.

\section{Methods}

Cell lines. Different human normal or tumor cell lines were obtained commercially (American Type Culture Collection, Rockville, MD). These included ME180 (cervical carcinoma), BT20 (breast carcinoma), HT29, SKC01 and WIDr (colon adenocarcinomas), SKLU1 and A549 (lung carcinomas), and MRC5 and IMR90 (normal diploid lung cells). All cell lines were adherent and were maintained in $75-\mathrm{cm}^{2}$ tissue culture flasks (Becton, Dickinson \& Co., Salt Lake City, UT) in RPMI-1640 media with $10 \%$ fetal calf serum without antibiotics (complete medium) in a humidified atmosphere of $5 \% \mathrm{CO}_{2}$ in air at $37^{\circ} \mathrm{C}$. Peripheral blood mononuclear cells were obtained from the buffy coats of whole blood from normal human volunteers. After isolation on isolymph gradients (Pharmacia, Inc., Piscataway, NJ), peripheral blood mononuclear cells were washed twice in phosphatebuffered saline (PBS), suspended in a solution of $10 \%$ dimethyl sulfoxide plus $90 \%$ fetal calf serum (GIBCO, Grand Island, NY) and stored in liquid nitrogen until used. Lymphocytes were cultured at $5 \times 10^{5}$ cells/ml in RPMI-1640 media supplemented with $10 \%$ fetal calf serum without antibiotics for 3 or $7 \mathrm{~d}$ in flat-bottomed, 96-well microculture plates in $100 \mu \mathrm{l}$ of total volume in the presence or absence of a 1:80 dilution of phytohemagglutinin or pokeweed mitogen, respectively. 1 $\mu \mathrm{Ci}$ of $\left[{ }^{3} \mathrm{H}\right]$ thymidine was added to cultures $18-20 \mathrm{~h}$ before cells were harvested on filter paper. Cells were negative for mycoplasma.

Reagents. Purified recombinant human IFN- $\gamma$ and purified recombinant human tumor necrosis factor- $\alpha$ (TNF- $\alpha$ ) (Genentech, Inc., South San Francisco, CA) were reconstituted at $10^{7} \mathrm{U} / \mathrm{ml}$ and stored at $0-4{ }^{\circ} \mathrm{C}$ until use. IFN- $\gamma$ or TNF- $\alpha$ were further diluted into media with $10 \%$ fetal calf serum as required. $\left[{ }^{3} \mathrm{H}\right]$ Thymidine was obtained from Amersham Corp. (Arlington Heights, IL). Other enzymes, proteins and chemicals were obtained from Sigma Chemical Co. (St. Louis, MO).

Growth inhibition assays. Tumor cells were seeded in complete media at $1 \times 10^{5}$ cells $/ \mathrm{ml}, 100 \mu \mathrm{l}$ per well in 96-well microculture plates and cultured in the presence of various concentrations of IFN- $\gamma$ or TNF- $\alpha$ for $1-7 \mathrm{~d}$ in a humidified atmosphere of $5 \% \mathrm{CO}_{2}$ in air at $37^{\circ} \mathrm{C}$. Growth inhibition was assessed by measuring incorporation of $\left[{ }^{3} \mathrm{H}\right]-$ thymidine or by staining cells with crystal violet. Cells were pulsed with $1 \mu \mathrm{Ci}$ per well $\left[{ }^{3} \mathrm{H}\right]$ thymidine for $6 \mathrm{~h}$ and were harvested on filter paper. Incorporation of $\left[{ }^{3} \mathrm{H}\right]$ thymidine was determined with a liquid scintillation spectrometer. Alternatively, cells were stained with crystal violet by removing media from the microculture plates and adding $100 \mu \mathrm{l}$ per well crystal violet solution (15). After 10-15 min, the crystal violet solution was removed and plates were rinsed five to six times with distilled water. Optical density at $550 \mathrm{~nm}$ was measured with an ELISA plate reader. Both assays gave comparable results. Results are expressed as the percentage of control cell growth. Addition of other reagents such as tryptophan, 3-aminobenzamide or nicotinamide, as described in the text, did not alter control cell growth by $>10-20 \%$. In these experiments, effects of these additional reagents on IFN- $\gamma-$ me-

1. Abbreviations used in this paper: BSO, buthionine sulfoximine; dThd, thymidine; OTZ, 2-oxothiazolidine-4-carboxylate; RT, ribosyl transferase; TNF, tumor necrosis factor. diated inhibition of cell growth are expressed as the percentage of control cell growth in the presence of the added reagent. Cultures were performed in duplicate and optical density did not vary by $>5 \%$ in duplicate cultures. Each experiment was performed a minimum of three times with similar results, and positive experiments were repeated in subsequent experiments as positive controls. Different oxygen concentrations were obtained by purging sealed containers with $4 \%, 12 \%$, or $20 \%$ oxygen, $5 \% \mathrm{CO}_{2}$ and the balance with $\mathrm{N}_{2}$. Tissue culture plates were incubated within these sealed containers at $37^{\circ} \mathrm{C}$. Containers were purged with the appropriate mixture of gases daily. Oxygen concentration was determined with a blood gas analyzer.

Amino acid analysis. Culture media $(2 \mathrm{ml})$ were clarified with $0.2-\mu \mathrm{m}$ filters and analyzed with an Aminoanalyzer (Hewlett-Packard Co., Palo Alto, CA) by reversed-phase high-performance liquid chromatography. Amino acids were precolumn derivatized with $o$-phthaldialdehyde, and detected by fluorescence (16). Amino acids were identified and quantitated by comparison of retention times and peak heights to known standards.

Kynurenine production. After culture of tumor cells for $48 \mathrm{~h}$ in the presence or absence of IFN- $\gamma$, culture media was replaced with RPMI media without phenol red, vitamins or amino acids but with 100-500 $\mu \mathrm{M}$ L-tryptophan. Culture fluids were harvested after 6-24 h of incubation, clarified by filtration, and analyzed for content of tryptophan and kynurenine on an amino acid analyzer (Beckman Instruments, Inc., Palo Alto, CA). Tryptophan and kynurenine were precolumn derivatized with ninhydrin and identified and quantitated by comparing retention times and peak heights to known standards.

Intracellular glutathione concentrations. Intracellular glutathione concentrations were depleted by addition of buthionine sulfoximine (BSO, $0.2 \mathrm{mM}$ final concentration from a stock solution of $20 \mathrm{mM}$ in water) or were elevated by addition of 2-oxothiazolidine-4-carboxylate (OTZ, $10 \mathrm{mM}$ final concentration from a stock solution of $100 \mathrm{mM}$ in $0.1 \mathrm{M}$ Tris, $\mathrm{pH}$ 7.5) (17). Intracellular concentrations of glutathione were quantitated by flow cytometry utilizing monochlorobimane as previously described (18). Briefly, cells were incubated with $20 \mu \mathrm{M}$ monochlorobimane for $10 \mathrm{~min}$ and analyzed by flow cytometry using a dual-laser EPICS V (Coulter Electronics, Inc., Hialeah, CA). Cells were excited with $50 \mathrm{~mW} \mathrm{UV}$ and mean cellular fluorescence was calculated numerically.

Extraction and measurement of intracellular NAD and ATP. Tumor cells $\left(1 \times 10^{6}\right)$ were washed once in PBS and suspended in 0.5 $\mathrm{M}$ perchloric acid $(100 \mu \mathrm{l})$ at $0-4^{\circ} \mathrm{C}$. Lysates were clarified by centrifugation, neutralized with $1 \mathrm{M}$ potassium hydroxide, and frozen at $-20^{\circ} \mathrm{C}$ for $1-4 \mathrm{~d}$. NADH was completely degraded under these conditions. Intracellular concentrations of NAD were determined with an enzymatic cycling assay which was linear between 3 and 100 pmol NAD (19). Each well of a 96-well microculture plate contained $50 \mu \mathrm{l}$ of either cell extract or NAD standard, $20 \mu \mathrm{l}$ of alcohol dehydrogenase $(160 \mathrm{U} / \mathrm{ml})$, and $150 \mu \mathrm{l}$ of a mixture of $600 \mathrm{mM}$ ethanol; and $0.5 \mathrm{mM}$ methyl thiazolyl tetrazolium, $2 \mathrm{mM}$ phenazine ethosulfate, $5 \mathrm{mM}$ ethylenediaminetetraacetic acid, $1 \mathrm{mg} / \mathrm{ml}$ bovine serum albumin, and

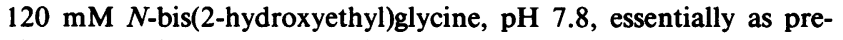
viously described. Plates were incubated at $37^{\circ} \mathrm{C}$ in the dark and optical density was measured at $500 \mathrm{~nm}$ (reduced methyl thiazolyl tetrazolium) after 15-30 min with an ELISA plate reader. This cycling method measures total NAD, both oxidized and reduced.

Intracellular levels of ATP were determined from acid extracts of cells by monitoring reduction of NADH spectrophotometrically at 340 $\mathrm{nm}$ in the presence of phosphoglyceric phosphokinase, glyceraldehyde phosphate dehydrogenase, and 3-phosphoglycerate with a kit obtained from Sigma Chemical Co. according to the manufacturer's instructions.

Measurement of superoxide anion and hydrogen peroxide. Tumor cells were cultured at $2 \times 10^{5}$ cells/ml in microtiter plates in the presence or absence of IFN- $\gamma$ for varying periods of time as indicated in the text. At the end of the incubation period, cultures were washed twice in PBS. Release of superoxide anion was measured over 1-2-h periods with the cytochrome $c$ reduction assay essentially as previously 
described (20). Release of superoxide anion as measured by reduction of cytochrome $c$ was linear for up to $3 \mathrm{~h}$ and was inhibited by addition of superoxide dismutase. Release of $\mathrm{H}_{2} \mathrm{O}_{2}$ was determined by measuring horseradish peroxidase-catalyzed oxidation of scopoletin essentially as previously described (21) using a microtiter plate-reading fluorometer.

Assay of ADP-RT activity. Cells $\left(2-5 \times 10^{6}, 2 \times 10^{5} / \mathrm{ml}\right)$ were cultured in the presence or absence of IFN- $\gamma$, removed from tissue culture plates with a tissue scraper, and harvested by centrifugation at $10,000 \mathrm{~g}$ for $10 \mathrm{~s}$. Cells were washed once in PBS and were suspended in $500 \mu \mathrm{l}$ of $56 \mathrm{mM}$ Hepes, $\mathrm{pH} 7.5$, containing $28 \mathrm{mM} \mathrm{KCl}, 28 \mathrm{mM}$ $\mathrm{NaCl}, 2 \mathrm{mM} \mathrm{MgCl}, 0.01 \%$ digitonin, and $250 \mu \mathrm{M}$ NAD $(0.5 \mu \mathrm{Ci} / \mathrm{ml}$ $\left[{ }^{3} \mathrm{H}\right] \mathrm{NAD}$ ) essentially as previously described (22). The amount of digitonin employed to permeabilize cells allowed uptake of trypan blue but did not lead to release of intracellular organelles (23). The permeabilized cells were incubated for $5-10 \mathrm{~min}$ at $37^{\circ} \mathrm{C}$ and the reaction was terminated by addition of trichloroacetic acid to yield a final concentration of $20 \%$ (wt/vol). Precipitated protein was washed three additional times with $10 \%$ trichloroacetic acid and was solubilized in $0.1 \mathrm{M}$ $\mathrm{NaOH}$. Radioactivity was determined by scintillation counting.

Measurement of catalase activity. Catalase activity of cell lysates was measured spectrophotometrically by determining the decrease in absorbance at $240 \mathrm{~nm}$ assuming an extinction coefficient of 39 $\mathrm{M}^{-1} \mathrm{~cm}^{-1}$ in the presence of $10 \mathrm{mM} \mathrm{H}_{2} \mathrm{O}_{2}$ in $50 \mathrm{mM}$ potassium phosphate buffer, pH $7.0(24,25)$.

Measurement of DNA strand breaks. The alkaline elution method, as previously described (26), was employed to measure DNA strand breaks. Approximately $1 \times 10^{6}\left[{ }^{14} \mathrm{C}\right]$ thymidine (dThd)-labeled tumor cells were mixed with an equal number of $\left[{ }^{3} \mathrm{H}\right] \mathrm{dTh}$ Th-labeled cells (internal standards) and collected onto filters. Cells were lysed on the

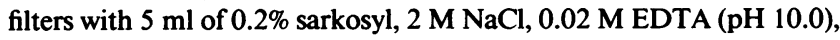
and then eluted with a solution of tetrapropylammonium hydroxideEDTA (pH 12.0). Results are expressed as the percentage of $\left[{ }^{14} \mathrm{C}\right] \mathrm{dThd}$ retained on the filters relative to the percentage of $\left[{ }^{3} \mathrm{H}\right] \mathrm{dThd}$ retained after elution with $30 \mathrm{ml}$ of the above $\mathrm{pH} 12.0$ solution. Under these conditions approximately $90 \%$ of the $\left[{ }^{3} \mathrm{H}\right] \mathrm{dThd}$-labeled DNA (control) was retained on the filters.

\section{Results}

Comparison of sensitivity of different tumor cell lines to growth inhibition by IFN- $\gamma$. Several different human tumor cell lines were evaluated to compare their relative sensitivity to growth inhibition by IFN- $\gamma$. As shown in Fig. 1, ME180 cells and A549 cells were inhibited by $75-80 \%$ on day 3 by $30-300$ $\mathrm{U} / \mathrm{ml}$ IFN- $\gamma$ whereas HT29, BT20, and MRC5 cells were inhibited by $55 \%, 0 \%$, or $5 \%$, respectively, by $1,000 \mathrm{U} / \mathrm{ml} \mathrm{IFN- \gamma \text {. }}$ Addition of up to $10,000 \mathrm{U} / \mathrm{ml}$ IFN- $\gamma$ did not increase growth inhibition of HT2', BT20, or MRC5 cells in the 3-d assay.

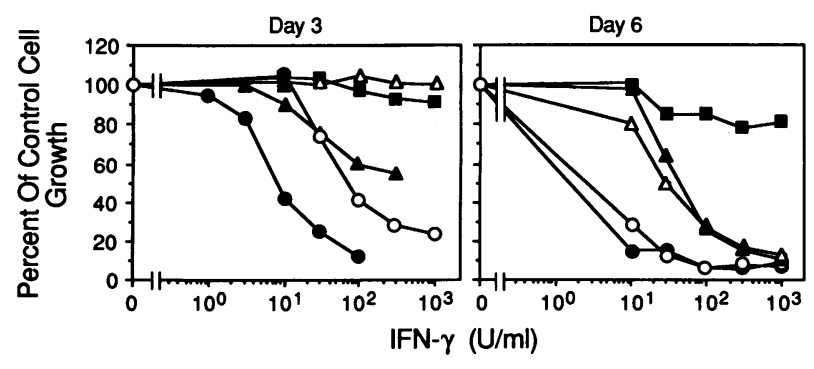

Figure 1. Inhibition of tumor cell growth by IFN- $\gamma$. Various tumor cell lines were cultured in the presence of increasing concentrations

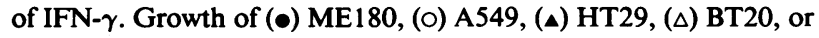
(๘) MRC 5 cells was evaluated on day 3 or 6 by the crystal violet assay and results are expressed as percentage of control.
Culture of these cells for $6 \mathrm{~d}$ in the presence of IFN- $\gamma$ increased susceptibility of ME 180 and A549 cells to inhibition by IFN- $\gamma$. Additionally, BT20 and HT29 cells were inhibited by $80-90 \%$ at concentrations of IFN- $\gamma$ between 100 and $300 \mathrm{U} / \mathrm{ml}$. The normal diploid lung cell, MRC5, was resistant to growth inhibition by IFN- $\gamma$ throughout the 6-d culture period. Other cell lines that have been evaluated include SKLU1, SKC01, WIDr, and IMR90. SKLU1 and WIDr cells appear to be similar to ME 180 and A549 cells and are inhibited by $80-90 \%$ by 30-300 U/ml IFN- $\gamma$ after $3 \mathrm{~d}$ of culture. SKC01 cells are resistant on day 3 but inhibited by $80-90 \%$ in the presence of $100-300 \mathrm{U} / \mathrm{ml}$ IFN- $\gamma$ by day 6 . Another normal diploid lung cell line, IMR90, was also resistant to inhibition by IFN- $\gamma$ under all conditions tested.

Reduced oxygen concentration reduces IFN- $\gamma$ antitumor activity. Experiments in tissue culture were performed in a concentration of oxygen equivalent to atmospheric oxygen concentrations $(\sim 21 \%)$. The oxygen concentration in tissue, however, is significantly lower than in the atmosphere. To evaluate the possibility that oxygen concentrations might influence the results of experiments performed in tissue culture, three different human tumor cell lines were cultured in $20 \%$, $12 \%$, and $4 \%$ oxygen in a humidified atmosphere of $5 \% \mathrm{CO}_{2}$ in the presence or absence of IFN- $\gamma$. Reduced oxygen tension decreased IFN- $\gamma$-mediated inhibition of growth for each cell line (Table I). The effect was most striking with the BT20 cell line where growth was $13 \%$ of control in the presence of IFN- $\gamma$ in an atmosphere of $20 \%$ oxygen but was $76 \%$ of control in the presence of IFN- $\gamma$ in an atmosphere of $4 \%$ or $12 \%$ oxygen. Activity of IFN- $\gamma$ was also reduced by greater than twofold in the other two cell lines tested, ME180 and A549, in the presence of reduced oxygen concentration. Increased concentrations of IFN- $\gamma$ could partially overcome the effects of reduced oxygen concentration but there was a lower limit of growth inhibition by IFN- $\gamma$ in the presence of reduced oxygen concentration which could not be overcome by additional IFN- $\gamma$ (data not shown). By contrast, activity of TNF- $\alpha$ against ME1 180 cells was not reduced in the presence of lower oxygen concentrations. However, the ability of tumor necrosis factor to increase the antiproliferative activity of IFN- $\gamma$ against BT20 cells was decreased by reducing oxygen concentration (Fig. 2). Concentrations of 100-300 U/ml IFN- $\gamma$ inhibited growth of BT20 cells in a 6-d assay (Fig. 1) but not in a 4-d assay. In the presence of $10 \mathrm{U} / \mathrm{ml} \mathrm{TNF-} \alpha$, as low as $1-10 \mathrm{U} / \mathrm{ml} \mathrm{IFN- \gamma}$ inhibited growth of BT20 cells by $70-80 \%$ in $20 \%$ oxygen in a 4-d assay. Inhibition was reduced to $30-40 \%$ in the presence of $12 \%$ oxygen and $10-20 \%$ in the presence of $4 \%$ oxygen.

IFN- $\gamma$ may inhibit tumor cell growth through an oxidative mechanism. A reduction in the concentration of oxygen would be expected to have a variety of effects on different cellular processes. It would also reduce the amount or number of oxygen species able to be produced by a cell or tissue. As shown in Table II, several antioxidants also prevented growth inhibition of the ME1 80 cell line by IFN- $\gamma$ in a 3-d assay. Of the antioxidants tested, $\beta$-mercaptoethanol and phenylbutazone increased cell growth in the presence of IFN- $\gamma$ from $24 \%$ of control to $82 \%$ and $83 \%$ of control, respectively, for the ME180 cell line, ascorbate increased cell growth to $52 \%$ of control and dimethyl sulfoxide and vitamin $E$ were minimally effective at preventing inhibition. Phenylbutazone or $\beta$-mercaptoethanol could be added $24 \mathrm{~h}$ after addition of IFN- $\gamma$ and still block inhibition. Phenylbutazone is also considered a non- 


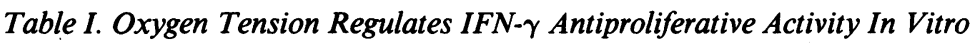

\begin{tabular}{|c|c|c|c|c|c|c|c|c|}
\hline \multirow[b]{4}{*}{ Oxygen } & \multicolumn{8}{|c|}{ Cell growth $\left(\mathrm{OD}_{s s o}\right)$} \\
\hline & \multicolumn{6}{|c|}{ IFN- $\gamma$} & \multirow{2}{*}{\multicolumn{2}{|c|}{$\begin{array}{c}\text { TNF- } \alpha \\
\text { ME180 }\end{array}$}} \\
\hline & \multicolumn{2}{|c|}{ ME180 } & \multicolumn{2}{|c|}{ A549 } & \multicolumn{2}{|c|}{ BT20 } & & \\
\hline & $-t$ & + & - & + & - & + & - & + \\
\hline$\%$ & & & & & & & & \\
\hline $20^{*}$ & $0.87^{\S}$ & $0.29(33)$ & 1.84 & $0.48(26)$ & 1.02 & $0.13(13)$ & 0.96 & 0.16 \\
\hline 12 & 0.67 & $0.44(66)$ & 1.68 & $0.74(44)$ & 0.42 & $0.32(76)$ & 0.89 & 0.09 \\
\hline 4 & 0.56 & $0.44(79)$ & 1.57 & $0.83(53)$ & 0.42 & $0.32(76)$ & 0.70 & 0.09 \\
\hline
\end{tabular}

* Tumor cells were cultured at $37^{\circ} \mathrm{C}$ in a humidified atmosphere of $5 \% \mathrm{CO}_{2}$ and either $20 \%, 12 \%$, or $4 \% \mathrm{O}_{2}$ and the remainder $\mathrm{N}_{2}$ for $3 \mathrm{~d}$ (ME180 or A549) or $6 \mathrm{~d}(\mathrm{BT} 20)$. ${ }^{\ddagger} \mathrm{ME} 180, \mathrm{~A} 549$, or BT20 cells were cultured in the presence $(+)$ or absence $(-)$ of 30,100, or $1,000 \mathrm{U} / \mathrm{ml}$ IFN- $\gamma$, respectively. ME1 80 cells were also cultured in the presence of $100 \mathrm{U} / \mathrm{ml} \mathrm{TNF-} \alpha .{ }^{\S}$ Cell growth was determined with the crystal violet assay. Numbers in parentheses represent percentage of control growth at the different percentages of oxygen.

steroidal anti-inflammatory agent and is co-oxygenated by the peroxidase activity of prostaglandin $\mathrm{H}$ synthetase (27). Of the cell lines tested, ME180 and A549 responded similarly to the presence of antioxidants. Inhibition of growth of the BT20 cell line by IFN- $\gamma$ was not affected by addition of these antioxidants. Taken together, these data suggest that IFN- $\gamma$ may mediate inhibition of growth of some tumor cell lines through an oxidative mechanism.

Potential role of oxidant formation in IFN- $\gamma$ activity. $\mathrm{Re}-$ duced oxygen species such as superoxide anion or hydrogen peroxide mediate cellular damage of various types in certain systems. Results in Table III show that tumor cells cultured with IFN- $\gamma$ released elevated amounts of superoxide anion. The two cell lines, ME180 and A549, increased release of superoxide anion by four- to fivefold after culture with IFN- $\gamma$ for 24-48 h. The two cell lines, BT20 and HT29, did not increase release of superoxide anion after culture with IFN- $\gamma$. This was true regardless of the concentration of IFN- $\gamma$ or the incubation period employed.

Table IV shows that one of the antioxidants which blocked growth inhibition by IFN- $\gamma, 2$-mercaptoethanol, also blocked IFN- $\gamma$-stimulated superoxide anion release in these same

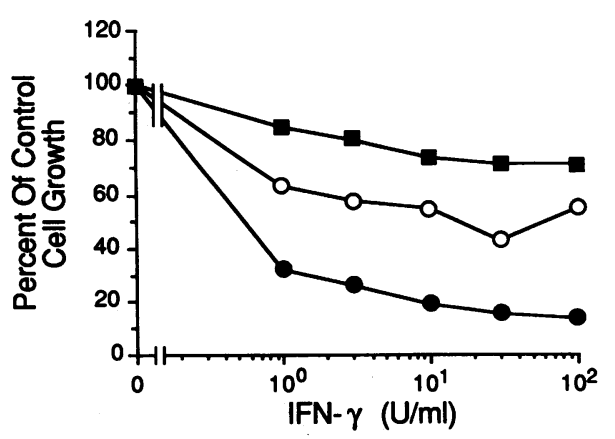

Figure 2. Oxygen tension regulates synergistic action of IFN- $\gamma$ and TNF- $\alpha$ against BT20 cells. BT20 cells were cultured in the presence or absence of IFN- $\gamma$ and the presence of $10 \mathrm{U} / \mathrm{ml} \mathrm{TNF-} \alpha$ for $4 \mathrm{~d}$ with oxygen pressure of $(\bullet) 20 \%$, (O) $12 \%$, or $(\boldsymbol{(}) 4 \%$. Cell growth was measured by the crystal violet assay. Control cell growth was $\mathrm{OD}_{550}$ 0.618 at $20 \%$ oxygen, 0.492 at $12 \%$ oxygen, and 0.416 at $4 \%$ oxygen. In the absence of IFN- $\gamma$, TNF- $\alpha$ did not inhibit growth of BT20 cells. cells. By contrast, phenylbutazone, which also prevented IFN- $\gamma$-mediated inhibition of ME180 cell growth did not block release of superoxide anion by these cells. This raises the possibility that these two inhibitors blocked activity by two distinct mechanisms. None of the four cell lines tested released increased amounts of $\mathrm{H}_{2} \mathrm{O}_{2}$ after culture with IFN- $\gamma$. This was true regardless of time of culture with IFN- $\gamma$ (from $30 \mathrm{~min}$ to $72 \mathrm{~h}$ ) or cell number. Two cell lines, BT20 and HT29, released about fourfold more $\mathrm{H}_{2} \mathrm{O}_{2}$ per hour than did the other two cell lines, $\mathrm{ME} 180$ and $\mathrm{A} 549$. Interestingly, $\mathrm{H}_{2} \mathrm{O}_{2}$ release by all four cell lines was somewhat depressed after culture for $>24 \mathrm{~h}$ with IFN- $\gamma$

Catalase catalyzes the decomposition of $\mathrm{H}_{2} \mathrm{O}_{2}$ while superoxide dismutase catalyzes the dismutation of $\mathrm{O}_{2}^{-}$to $\mathrm{H}_{2} \mathrm{O}_{2}$ and $\mathrm{O}_{2}$. If $\mathrm{O}_{2}^{-}$or $\mathrm{H}_{2} \mathrm{O}_{2}$ contributed to the inhibition of tumor cell growth mediated by IFN- $\gamma$, then these enzymes may effectively compete for their substrates and inhibit IFN- $\gamma$ activity. These results are shown in Table V. Catalase partially prevented inhibition of growth of BT20 and HT29 cells by IFN- $\gamma$

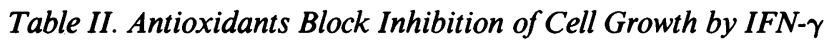

\begin{tabular}{lccc}
\hline & \multicolumn{3}{c}{ Control cell growth } \\
\cline { 2 - 4 } \multicolumn{1}{c}{ IFN- $\gamma$} & ME180 & A549 & BT20 \\
\hline & & $\%$ & \\
IFN- $\gamma$ plus & 24 & 35 & 25 \\
$1 \mathrm{mM}$ ascorbate & 52 & 50 & 24 \\
$10 \mu \mathrm{M}$ uric acid & 32 & $\mathrm{ND}^{*}$ & ND \\
$100 \mathrm{mM}$ dimethylsulfoxide & 41 & 46 & ND \\
$500 \mu \mathrm{M} \beta$-mercaptoethanol & 82 & 102 & 23 \\
$10 \mu \mathrm{M}$ phenylbutazone & 83 & 77 & 26 \\
$50 \mu \mathrm{M}$ vitamin E & 40 & ND & ND
\end{tabular}

IFN- $\gamma(100,10$, or $30 \mathrm{U} / \mathrm{ml})$ was cultured with the cell lines BT20, ME180, or A549, respectively, which differ in their sensitivity to this lymphokine. An equal degree of inhibition of cell growth was obtained by varying the concentration of IFN- $\gamma$ and the length of the assay as shown in Fig. 1. On day 3, growth of ME180 or A549 cells was measured with the crystal violet assay. Cell growth by BT20 cells was measured on day 7. Results are expressed as the percentage of control cell growth.

* ND, not done. 
Table III. Oxidant Release by Tumor Cells

\begin{tabular}{|c|c|c|c|c|}
\hline \multirow[b]{2}{*}{ Cell line } & \multicolumn{2}{|c|}{$\mathrm{O}_{2}^{-}$released } & \multicolumn{2}{|c|}{$\mathrm{H}_{2} \mathrm{O}_{2}$ released } \\
\hline & $-\mathrm{IFN}-\boldsymbol{\gamma}^{*}$ & $+\mathrm{IFN}-\gamma$ & $-\mathrm{IFN}-\gamma$ & + IFN- $\gamma$ \\
\hline & \multicolumn{4}{|c|}{ nmol/h per $10^{6}$ cells } \\
\hline ME180 & $3.9^{\ddagger}$ & 12.6 & $0.6^{\S}$ & 0.2 \\
\hline A549 & 4.1 & 20.3 & 1.0 & 0.5 \\
\hline BT20 & 2.1 & 1.7 & 3.9 & 1.9 \\
\hline HT29 & 2.6 & 2.8 & 4.4 & 2.3 \\
\hline
\end{tabular}

* Tumor cells were cultured for $24 \mathrm{~h}$ in the presence $(+)$ or absence $(-)$ of $10 \mathrm{U} / \mathrm{ml} \mathrm{IFN-} \gamma$ (ME180 and A549) or $100 \mathrm{U} / \mathrm{ml} \mathrm{IFN- \gamma}$ (BT20 and HT29).

${ }^{\ddagger}$ Rate of superoxide anion release from tumor cell cultures was measured with the cytochrome $c$ reduction assay (see Methods).

${ }^{\S}$ Rate of $\mathrm{H}_{2} \mathrm{O}_{2}$ release was determined by measuring decrease in scopoletin fluorescence in the presence of horseradish peroxidase.

but not of ME180 or A549 cells. These cell lines also produced more $\mathrm{H}_{2} \mathrm{O}_{2}$ than did ME180 or A549 cells. Under the conditions employed, superoxide dismutase did not protect tumor cells from inhibition by IFN- $\gamma$. Higher concentrations of superoxide dismutase alone were also somewhat inhibitory.

Intracellular glutathione concentration regulates antitumor activity of IFN- $\gamma$ in vitro. Results described above indicated that inhibition of tumor cell growth in vitro by IFN- $\gamma$ was sensitive to oxygen concentration. Changes in intracellular glutathione concentration have been shown to affect sensitivity of tumor cells to growth inhibition by various oxidizing species (28). Thus it seemed possible that changes in intracellular glutathione might affect the activity of IFN- $\gamma$ against certain tumor cell lines. These data are shown in Fig. 3. The percentage of control cell growth (ME180) is $20-30 \%$ in the presence of $10-30 \mathrm{U} / \mathrm{ml}$ IFN- $\gamma$ in a 3-d culture. BT2 0 cells are inhibited by $100-300 \mathrm{U} / \mathrm{ml} \mathrm{IFN-} \gamma$ in a 5-7-d culture. Elevation of glutathione levels by $10 \mathrm{mM}$ OTZ increased growth in the presence of $100 \mathrm{U} / \mathrm{ml} \mathrm{IFN-} \gamma$ from $10 \%$ to $65 \%$ for BT20 cells and from $30 \%$ to $85 \%$ for ME 180 cells in the presence of $10 \mathrm{U} / \mathrm{ml}$ IFN- $\gamma$. Conversely, reduction of glutathione levels with $0.2 \mathrm{mM}$ BSO decreased growth of BT20 cells in the presence of $30 \mathrm{U} / \mathrm{ml}$ IFN- $\gamma$ from $60 \%$ to $10 \%$ of control and decreased growth of ME180 cells in the presence of $3 \mathrm{U} / \mathrm{ml}$

Table IV. Inhibition of Superoxide Anion Release by 2-Mercaptoethanol

\begin{tabular}{ccc}
\hline & \multicolumn{2}{c}{ Superoxide anion released } \\
\cline { 2 - 3 } Inhibitor* & - IFN- $\gamma$ & + IFN- $\gamma$ \\
\hline & \multicolumn{2}{c}{$n$ mol/h per $10^{6}$ cells } \\
- & 3.6 & 17.1 \\
$10 \mu \mathrm{M}$ phenylbutazone & 4.1 & 20.3 \\
$500 \mu \mathrm{M}$ 2-mercaptoethanol & 3.3 & 5.9 \\
\hline
\end{tabular}

* A549 cells $\left(2 \times 10^{6} / \mathrm{ml}\right)$ were cultured for $24 \mathrm{~h}$ in the presence $(+)$ or absence (-) of IFN- $\gamma$ and phenylbutazone or 2-mercaptoethanol. ‡ Cell cultures were washed twice and rate of superoxide anion release measured with the cytochrome $c$ reduction assay (see Methods).
Table V. Effect of Catalase or Superoxide Dismutase on IFN-r Activity

\begin{tabular}{lccc}
\hline & \multicolumn{3}{c}{ Control cell growth } \\
\cline { 2 - 4 } Cell line & No addition & Catalase $^{*}$ & Superoxide dismutase \\
\hline & & \multicolumn{2}{c}{} \\
ME180* & $32^{\S}$ & 33 & 41 \\
A549 & 31 & 30 & 29 \\
HT29 & 38 & 73 & 24 \\
BT20 & 34 & 61 & 21
\end{tabular}

* ME180 or A549 cells were cultured in the presence or absence of 10 or $30 \mathrm{U} / \mathrm{ml}$ IFN- $\gamma$, respectively for $3 \mathrm{~d}$. HT29 or BT20 cells were cultured in the presence or absence of $100 \mathrm{U} / \mathrm{ml} \mathrm{IFN-} \gamma$ for $5 \mathrm{~d}$.

${ }^{\ddagger}$ Catalase $(150 \mu \mathrm{g} / \mathrm{ml})$ or superoxide dismutase $(300 \mathrm{U} / \mathrm{ml})$ were added at culture initiation.

${ }^{\S}$ Cell growth was determined with the crystal violet assay. Results are presented as the percentage of control cell growth in the absence of IFN- $\gamma$ but where indicated, in the presence of catalase or superoxide dismutase. Addition of these enzymes alone did not appreciably affect growth rates.

IFN- $\gamma$ from $90 \%$ to $50 \%$ of control. Addition of BSO or OTZ to cultures $24 \mathrm{~h}$ after addition of IFN- $\gamma$ also increased or decreased respectively, the sensitivity of tumor cells to inhibition but to a lesser degree.

Addition of IFN- $\gamma$ alone to either BT20 cells or ME180 cells did not alter intracellular glutathione concentrations even late in the culture period when cell growth was completely inhibited. In the presence of BSO, intracellular glutathione levels were decreased by $75-80 \%$ throughout the $6-d$ culture of BT20 cells whereas intracellular concentrations of glutathione were only decreased during the first $24 \mathrm{~h}$ of the culture of ME1 80 cells. Addition of OTZ increased glutathione concentration by $20-50 \%$ but this increase was transient and glutathione concentration decreased to control levels within $24 \mathrm{~h}$ (data not shown). Sensitivity of other cell lines to inhibition by IFN- $\gamma$ was also affected by raising or lowering intracellular glutathione concentration. The greatest effects were seen with BT20 and SKC01 cells. HT29 and ME180 cells were less affected and A549 cells were least affected by addition of BSO or OTZ. These differences paralleled the degree of change in glu-

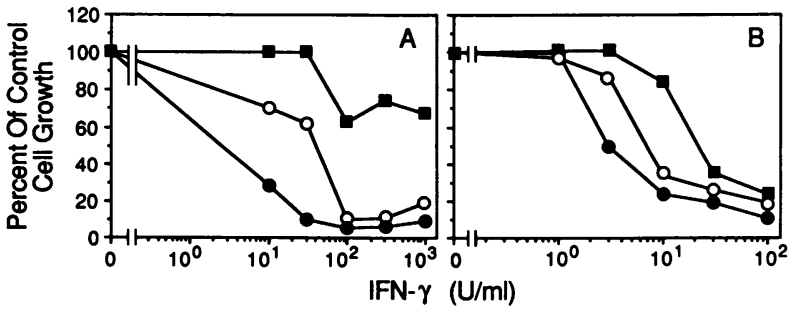

Figure 3. Elevation or reduction of intracellular glutathione reduces or increases sensitivity of tumor cells to inhibition by IFN- $\gamma$ respectively. Either $(A)$ BT20 or $(B)$ ME1 180 cells were incubated in the presence or absence of IFN- $\gamma(\bullet, O, \square)$ for 6 or $3 \mathrm{~d}$, respectively. Glutathione levels were increased by addition of $10 \mathrm{mM} \mathrm{OTZ} \mathrm{(๘),} \mathrm{de-}$ creased by addition of $0.2 \mathrm{mM}$ BSO (๑). 
tathione concentrations by addition of BSO or OTZ to the different cell lines. For example, glutathione concentration of BT20 cells was substantially reduced by addition of BSO but glutathione concentration of A549 cells was only slightly reduced by addition of BSO. Under conditions employed in these experiments, addition of BSO or OTZ did not alter growth rates of the various tumor cell lines in the absence of IFN- $\gamma$ (data not shown). Also, it was necessary to add BSO or OTZ early in the culture period to alter sensitivity of the various cell lines to inhibition by IFN- $\gamma$.

Tryptophan prevents IFN- $\gamma$-mediated inhibition of tumor cell growth. As shown in Fig. 4, addition of tryptophan prevented inhibition of cell growth by IFN- $\gamma$. The concentration of IFN- $\gamma$ required to yield 50\% inhibition of growth by ME180 cells was $3 \mathrm{U} / \mathrm{ml}$ in the absence of added tryptophan but was $700 \mathrm{U} / \mathrm{ml}$ in the presence of $1 \times 10^{-3} \mathrm{M}$ tryptophan. Increased concentrations of tryptophan increased the amount of IFN- $\gamma$ necessary to achieve equivalent inhibition of growth of ME180 cells. The titration of inhibition of growth vs. IFN- $\gamma$ concentration in the presence of increasing tryptophan concentrations yielded a series of almost parallel curves. These data are portrayed in Fig. 4 (inset) as the log of the dose of IFN- $\gamma$ required to yield $50 \%$ inhibition vs. the $\log$ of the concentration of tryptophan. The $\log$ of the $\mathrm{ID}_{50}$ was proportional to the $\log$ of the tryptophan concentration in the media as the tryptophan concentration was increased.

Results shown in Table VI indicate that the ability to inhibit IFN- $\gamma$ activity was specific for L-tryptophan. Several other aromatic amino acids such as tyrosine, phenylalanine, or histidine or other essential amino acids such as methionine, isoleucine, or lysine at similar concentrations $\left(5 \times 10^{-4} \mathrm{M}\right)$ did not affect IFN- $\gamma$-mediated inhibition of growth of ME180 cells. In addition, D-tryptophan failed to protect against the inhibitory effects of IFN- $\gamma$ at concentrations which were 10fold greater than concentrations of L-tryptophan which showed partial protection.

The addition of L-tryptophan did not prevent IFN- $\gamma-$ mediated inhibition of cell growth by all tumor cell lines. Further, the addition of L-tryptophan did not prevent growth inhibition of ME1 80 cells by TNF- $\alpha$ (data not shown). The two cell lines

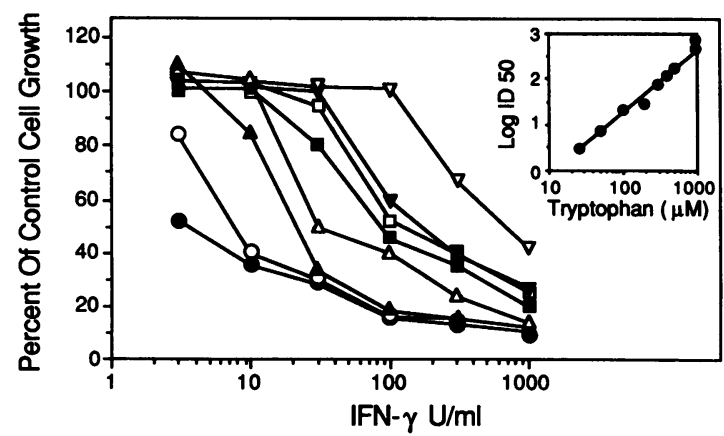

Figure 4. Increasing concentrations of tryptophan increase the concentration of IFN- $\gamma$ required to inhibit cell growth. ME180 cells were cultured in the presence of the indicated concentrations of

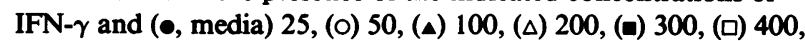
(v) 500 , or $(\nabla) 1,000 \mu \mathrm{M}$ tryptophan. Inhibition of cell growth was assayed on day 3 of culture with the crystal violet assay. (Inset) Comparison of the logarithm of the concentration of IFN- $\gamma$ which yields $50 \%$ inhibition of cell growth with the concentration of tryptophan present in tissue culture media at initiation of culture.
Table VI. Effects of L-tryptophan or Other Amino Acids

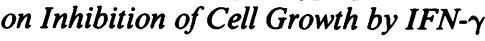

\begin{tabular}{cc}
\hline & $\begin{array}{c}\text { ME180 } \\
\text { Control cell growth }\end{array}$ \\
\hline & $\%$ \\
IFN- $\gamma(30 \mathrm{U} / \mathrm{ml})$ & 29 \\
$+3 \times 10^{-4} \mathrm{M}$ L-tryptophan & 87 \\
$+3 \times 10^{4} \mathrm{M}$ L-tyrosine & 39 \\
$+3 \times 10^{-4} \mathrm{M}$ L-phenylalanine & 34 \\
$+3 \times 10^{-4} \mathrm{M}$ L-histidine & 39 \\
$+3 \times 10^{-4} \mathrm{M}$ L-leucine & 29 \\
$+3 \times 10^{-4} \mathrm{M}$ L-methionine & 27 \\
$+3 \times 10^{-4} \mathrm{M}$ L-isoleucine & 31 \\
$+3 \times 10^{-4} \mathrm{M}$ L-lysine & 26 \\
$+3 \times 10^{-4} \mathrm{M}$ D-tryptophan & 25 \\
$1.6 \times 10^{-3} \mathrm{M}$ D-tryptophan & 27 \\
\hline
\end{tabular}

IFN- $\gamma$ was cultured with ME1 80 cells as described in Methods. On day 3 , cell growth was measured with the crystal violet assay. Results are expressed as percent of control cell growth.

that were most sensitive to low concentrations of IFN- $\gamma$, ME180 and A549, were protected by the addition of L-tryptophan (Table VII). Other cell lines that were not affected by the addition of L-tryptophan were SKLU1, HT29, and BT20. Growth of these cell lines was only inhibited after 5-6 d of culture with IFN- $\gamma$.

Certain tumor cells exposed to IFN- $\gamma$ consume L-tryptophan at accelerated rates. The above results support the hypothesis that loss of free or protein-associated tryptophan may mediate inhibition of growth of certain cell lines by IFN- $\gamma$. To further investigate this possibility, media was harvested from three different tumor cell lines and one nontransformed diploid cell line after culture with IFN- $\gamma$ for various periods of time and assayed for content of the different amino acids. Results shown in Fig. 5 compare loss of tryptophan from cul-

Table VII. Comparison of the Protective Effect of Tryptophan on IFN-r-mediated Inhibition of Cell Growth

\begin{tabular}{lrrrrr}
\hline & & & & \multicolumn{2}{c}{ Control cell growth } \\
\cline { 5 - 5 } Cell line* & IFN- $\gamma$ & $\begin{array}{c}\text { Day of } \\
\text { assay }\end{array}$ & & -Tryptophan & +Tryptophan $^{*}$ \\
\hline ME180 & $U / m l$ & & & \\
A549 & 10 & 3 & $22^{\|}$ & 94 \\
SKLU1 & 30 & 3 & 28 & 102 \\
SKC01 & 100 & 3 & 55 & 62 \\
HT29 & 100 & 3 & 18 & 19 \\
BT20 & 300 & 7 & 14 & 21 \\
MRC5 & 1,000 & 7 & 11 & 14 \\
& 10,000 & 3 & 95 & 96 \\
\hline
\end{tabular}

* Cell lines were seeded in 96-well microculture wells at $1 \times 10^{5}$ cells $/ \mathrm{ml}, 100 \mu \mathrm{l}$ per well with the indicated concentrations of IFN- $\gamma$. ‡ "-Tryptophan" designates no additional tryptophan added to RPMI-1640 media which contains $2.5 \times 10^{-5} \mathrm{M}$ tryptophan as measured by amino acid analysis.

$\S$ "+Tryptophan" designates control RPMI-1640 media with additional L-tryptophan to yield a final concentration of $8 \times 10^{-4} \mathrm{M}$.

"Tumor cell growth was determined using the crystal violet assay. 
ture media from various cell types in the presence or absence of IFN- $\gamma$. The two cell lines, ME180 and A549, which were protected from IFN- $\gamma$-mediated inhibition by addition of exogenous tryptophan, consumed virtually all tryptophan present in the media within $3 \mathrm{~d}$. Cells from these two lines did not consume $>25 \%$ of the tryptophan in media in the absence of IFN- $\gamma$. By contrast, IFN- $\gamma$-treated HT29 cells, which were not protected from inhibition by tryptophan, did not consume tryptophan from media faster than cells not exposed to IFN- $\gamma$. Another cell line, BT20, was also not protected from inhibition by exogenous tryptophan. This cell line did consume somewhat more tryptophan in the presence than in the absence of IFN- $\gamma$. These cells, when exposed to IFN- $\gamma$, did not totally deplete the media of L-tryptophan as was the case for ME180 and A549 cells. One cell line, MRC5, a normal diploid lung cell, showed complete depletion of tryptophan from the media after $3 \mathrm{~d}$ of culture with IFN- $\gamma$, but in contrast to the other cell lines, was resistant to growth inhibition by IFN- $\gamma$. Similar results were obtained with another normal cell line, IMR90. There was no difference in the level of other amino acids in media from cultures of control cells vs. cells exposed to IFN- $\gamma$.

Differences in growth rates of normal diploid and transformed cells in the presence of reduced tryptophan levels. Both ME180 and A549 tumor cell lines depleted media of tryptophan and did not divide after culture with IFN- $\gamma$. By contrast, the normal diploid lung cell line, MRC5, was not growth inhibited by IFN- $\gamma$ but did deplete tryptophan from the media. This suggests that either tryptophan depletion does not cause inhibition of cell division by ME 180 and A549 cells, or that division by tumor cells is much more sensitive to low tryptophan concentration than is division by normal diploid cells. To address the latter possibility, normal diploid cells and tumor cells were cultured in RPMI-1640 medium with dialyzed fetal serum and varying concentrations of either tryptophan or leucine or methionine, two other essential amino acids. These results are shown in Fig. 6. Tumor cell lines evalu-

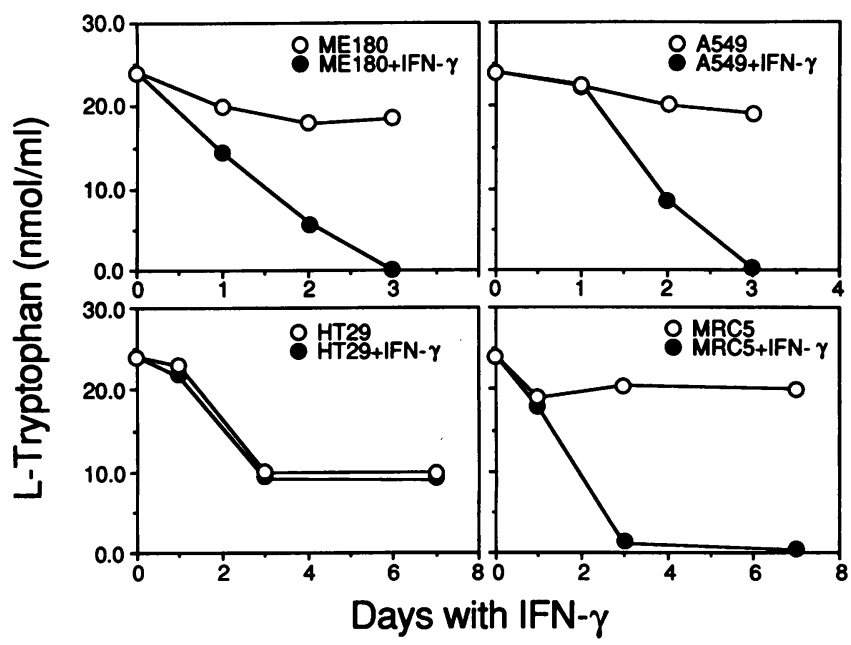

Figure 5. Cells cultured with IFN- $\gamma$ consume tryptophan. The cell lines, ME180 and A549, were cultured in the (๑) presence or (0) absence of $10 \mathrm{U} / \mathrm{ml} \mathrm{IFN-} \gamma$. The cell line HT29 and MRC5 were cultured in the $(\bullet)$ presence or $(0)$ absence of $1000 \mathrm{U} / \mathrm{ml}$ IFN- $\gamma$. Culture media were harvested on the indicated days and analyzed for tryptophan concentration by amino acid analysis.

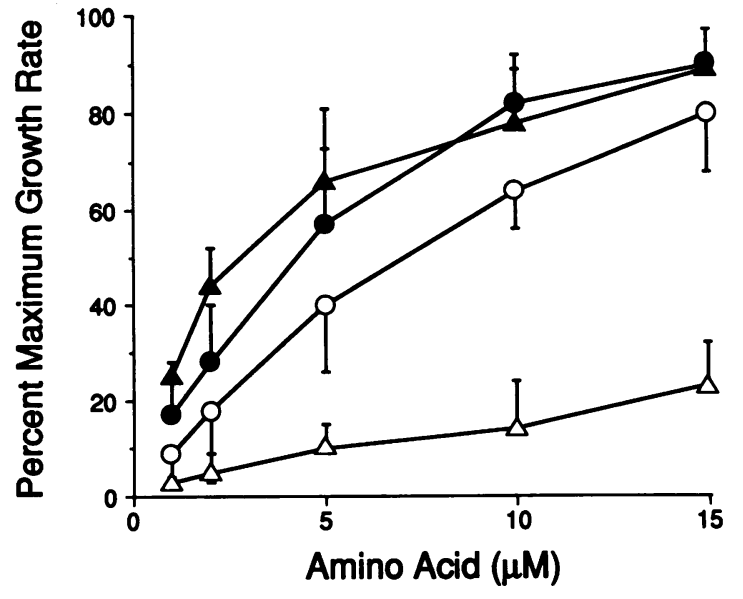

Figure 6. Inhibition of tumor cell growth by low tryptophan. Tumor cells, ME180, A549, HT29 or SKCO1 or normal diploid cells, MRC5, IMR90, or mitogen-activated lymphocytes, were cultured for $5 \mathrm{~d}$ in RPMI-1640 media with varying amounts of either ( $(\bullet)$ methionine, (o) leucine, or $(\Delta, \Delta)$ tryptophan. Results are expressed as the percentage of maximum growth rate obtained with complete medium. The range of growth rates of the different cell lines is shown by the error bars. Cultures in the presence of varying amounts of tryptophan are divided into $(\Delta)$ tumor cell responses and $(\Delta)$ normal diploid cell responses. The concentrations of methionine, leucine, and tryptophan in complete media are 100,396 , and $49 \mu \mathrm{M}$, respectively.

ated in this experiment were ME180, A549, HT29, and SKLU1. Normal diploid cells included MRC5, IMR90, and mitogen-stimulated peripheral blood lymphocytes. Results are expressed as the percentage of maximum growth rate as a function of the concentration of individual amino acids. The standard deviation of the different cell lines is also shown. Change in growth rates as a function of methionine or leucine concentration was similar for normal diploid and for tumor cells. By contrast, there was a striking difference between growth rates of normal diploid and tumor cells when tryptophan concentration was the variable. For example, in the presence of $5 \mu \mathrm{M}$ tryptophan, tumor cells achieved $\sim 5 \%$ of their maximum growth rate whereas normal diploid cells achieved $\sim 60 \%$ of their maximum growth rate. These data support the notion that the differential effects of IFN- $\gamma$ on the growth rates of certain normal and transformed cell lines may be attributed to the response of individual cell lines to reduced tryptophan concentration.

Production of kynurenine by cells exposed to IFN- $\gamma$. The product of oxidation of tryptophan by either indoleamine 2,3dioxygenase or tryptophan 2,3-dioxygenase is formylkynurenine (13). Most cells also have kynurenine formamidase which produces kynurenine from formylkynurenine. ME180 cells (1 $\times 10^{5} / \mathrm{ml}$ ) were cultured with or without 10 or $100 \mathrm{U} / \mathrm{ml}$ IFN- $\gamma$ in complete media. After $48 \mathrm{~h}$, cells were washed and cultured in RPMI-1640 medium without amino acids except 100 or $500 \mu \mathrm{M}$ tryptophan in dialyzed fetal calf serum. Culture media was harvested after 6 or $24 \mathrm{~h}$, filtered, and analyzed for tryptophan and kynurenine concentrations by amino acid analysis. After 6 or $24 \mathrm{~h}$ of culture, cells not exposed to IFN- $\gamma$ had produced no kynurenine and tryptophan concentration in the media was unchanged. Media (100 $\mu \mathrm{M}$ tryptophan) from cells exposed to $10 \mathrm{U} / \mathrm{ml}$ IFN- $\gamma$ had a tryptophan concentra- 
tion of $70 \mu \mathrm{M}$ after $6 \mathrm{~h}$ and $30 \mu \mathrm{M}$ after $24 \mathrm{~h}$. The kynurenine concentration was $20 \mu \mathrm{M}$ after $6 \mathrm{~h}$ and $50 \mu \mathrm{M}$ after $24 \mathrm{~h}$. More kynurenine (150 $\mu \mathrm{M}$ after $24 \mathrm{~h}$ ) was produced from cells cultured in $500 \mu \mathrm{M}$ tryptophan than in $100 \mu \mathrm{M}$ tryptophan.

Inhibitors of IFN- $\gamma$ activity also prevent loss of tryptophan. Phenylbutazone and 2-mercaptoethanol prevent growth inhibition of ME180 and A549 cells mediated by IFN- $\gamma$. These agents, at concentrations which inhibit IFN- $\gamma$ activity, also prevent the loss of tryptophan from media (Fig. 7). ME180 or A549 cells were cultured in the presence of 3-30 U/ml IFN- $\gamma$ in the presence or absence of phenylbutazone or 2-mercaptoethanol. Culture media was harvested after $48 \mathrm{~h}$. In the presence of IFN- $\gamma$, loss of tryptophan from cultures of ME180 and A549 cells was almost complete. Loss of tryptophan was almost completely inhibited in the presence of phenylbutazone or 2-mercaptoethanol.

Inhibitors of ADP-RT block IFN- $\gamma$-mediated inhibition of cell growth. Inhibition of growth of several other cell lines was unaffected by addition of tryptophan and these cells did not deplete media of tryptophan when cultured with IFN- $\gamma$. On the basis of these results, it was apparent that IFN- $\gamma$ inhibited tumor cell proliferation by at least one additional mechanism dependent upon oxygen concentration. Activation of intracellular ADP-RT by agents that cause DNA strand breaks leads to inhibition of cell growth or loss in cell viability (12). Reactive oxygen species have been shown to mediate the DNA strand breaks caused by a wide variety of agents (14). Two inhibitors of ADP-RT, 2-aminobenzamide and nicotinamide, prevent ADP ribosylation of proteins, the loss in NAD, and inhibition of cell growth or loss in cell viability caused by activation of ADP-RT (29). As shown in Fig. 8, inhibition of growth of BT 20 cells by IFN- $\gamma$ was blocked by addition of 10 $\mathrm{mM}$ nicotinamide or $10 \mathrm{mM}$ 3-aminobenzamide. Under these conditions, nicotinamide or 3-aminobenzamide did not affect growth of BT2 20 cells in the absence of IFN- $\gamma$. Increased concentrations of ADP-RT inhibitors inhibited the growth of BT20 cells and lower concentrations of ADP-RT inhibitors were less effective at blocking the inhibitory activity of IFN- $\gamma$.

Other cell lines employed in these studies were also tested for sensitivity to growth inhibition by IFN- $\gamma$ in the presence or absence of ADP-RT inhibitors. These results are shown in Table VIII. Growth inhibition of ME180 and A549 was not affected by addition of ADP-RT inhibitors. By contrast, inhibition of growth of those cell lines (BT20, HT29, and SKLU1),

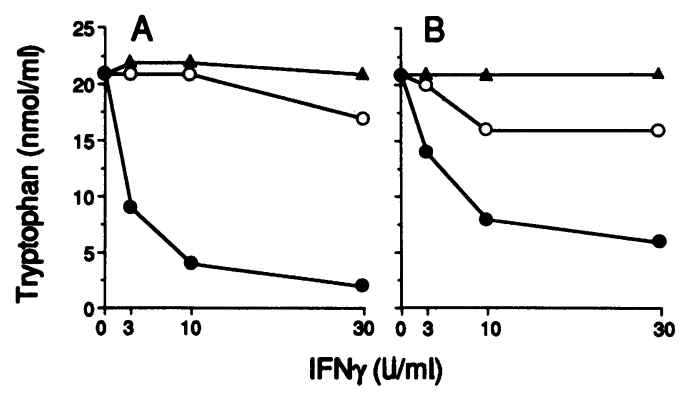

Figure 7. Inhibition of tryptophan loss in the presence of 2-mercaptoethanol or phenylbutazone. ME180 $(A)$ and A549 $(B)$ cells were cultured in the presence or absence of IFN- $\gamma(\bullet)$ and in the presence of (O) 2-mercaptoethanol or ( $\triangle$ ) phenylbutazone for $48 \mathrm{~h}$. Culture media were harvested on the indicated days and analyzed for tryptophan concentration by amino acid analysis.

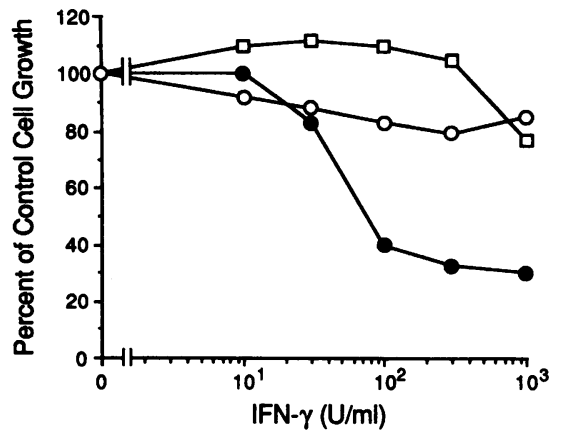

Figure 8. Inhibitors of ADP-RT block IFN- $\gamma$-mediated inhibition of BT20 cells. BT20 cells were cultured in the presence or absence of various concentrations of IFN- $\gamma$ and in the (๑) absence or presence of () $5 \mathrm{mM}$ nicotinamide or (0) $10 \mathrm{mM}$ 3-aminobenzamide for $5 \mathrm{~d}$. Cell growth was determined by the crystal violet assay. Control cell growth was $\mathrm{OD}_{550}$ of 0.640 and 0.57 or 0.69 in the presence of $5 \mathrm{mM}$ nicotinamide or $10 \mathrm{mM} 3$-aminobenzamide, respectively.

which did not appear to employ catabolism of tryptophan as a mechanism of inhibition, was blocked by addition of ADP-RT inhibitors. Inhibition of growth of one cell line, SKCO1, by IFN- $\gamma$ was not affected by addition of either tryptophan or inhibitors of ADP-RT.

Activation of ADP-RT is known to result in the ADP ribosylation of intracellular proteins and has been shown to result in the elimination of intracellular NAD (30). Inhibitors of ADP-RT such as 3-aminobenzamide or nicotinamide have been shown to prevent depletion of $\operatorname{NAD}(13,19)$. As shown in Table IX, culture of tumor cells in the presence of IFN- $\gamma$ resulted in almost complete loss of intracellular NAD. Loss of intracellular NAD was not apparent until late in the culture period, was proportional to the amount of IFN- $\gamma$ added and preceded the effects of IFN- $\gamma$ on cell growth or viability by several hours (data not shown). The normal fibroblast line, MRC5, was not depleted of intracellular NAD or growth inhibited after culture with IFN- $\gamma$. These cells were stimulated by IFN- $\gamma$ to deplete extracellular tryptophan from the media

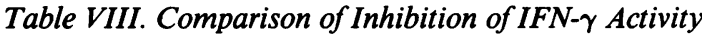
in Tumor Cell Lines by ADP-RT Inhibitors

\begin{tabular}{|c|c|c|c|c|c|}
\hline \multirow[b]{2}{*}{ Cell line* } & \multirow[b]{2}{*}{ IFN- $\gamma$} & \multirow[b]{2}{*}{$\begin{array}{c}\text { Day of } \\
\text { assay }\end{array}$} & \multicolumn{3}{|c|}{ Control cell growth with ADP-RT inhibitors } \\
\hline & & & None & $\begin{array}{l}\text { Nicotinamide } \\
\quad(5 \mathrm{mM})\end{array}$ & $\begin{array}{l}\text { 3-Aminobenzamide } \\
\text { (10 mM) }\end{array}$ \\
\hline & $U / m l$ & & \multicolumn{3}{|c|}{$\%$} \\
\hline ME180 & 10 & 3 & $22^{\ddagger}$ & 30 & 26 \\
\hline A549 & 30 & 3 & 31 & 37 & 32 \\
\hline SKC01 & 300 & 3 & 26 & 34 & 25 \\
\hline SKLU1 & 300 & 5 & 29 & 91 & 77 \\
\hline HT29 & 100 & 5 & 20 & 76 & 62 \\
\hline BT20 & 100 & 5 & 31 & 101 & 104 \\
\hline
\end{tabular}

* Cell lines were cultured for the indicated periods of time in the presence or absence of IFN- $\gamma$ and in the presence or absence of 5 mM nicotinamide or $10 \mathrm{mM}$ 3-aminobenzamide.

‡ Cell growth was determined with the crystal violet assay. The presence of $5 \mathrm{mM}$ nicotinamide or $10 \mathrm{mM}$ 3-aminobenzamide did not significantly affect control cell growth. 
Table IX. IFN- $\gamma$ Causes Depletion of Intracellular NAD Pools

\begin{tabular}{cccc}
\hline Cell line & $\begin{array}{c}\text { Day of } \\
\text { assay }\end{array}$ & IFN- $\gamma$ & NAD $^{\ddagger}$ \\
\hline \multirow{3}{*}{ ME180* } & & $U / m l$ & $\begin{array}{c}\text { nmol/mg } \\
\text { protein }\end{array}$ \\
& 3 & 0 & 2.1 \\
HT29 & 3 & 30 & $<0.3(<15)^{\S}$ \\
& 5 & 0 & 9.0 \\
BT20 & 5 & 100 & $1.4(16)$ \\
& 5 & 0 & 3.8 \\
A549 & 5 & 100 & $0.6(16)$ \\
& 3 & 0 & 2.6 \\
MRC5 & 3 & 30 & $<0.3(<13)$ \\
& 5 & 0 & 10.9 \\
& 5 & 300 & $11.8(108)$ \\
\hline
\end{tabular}

* Cell lines were cultured in the presence or absence of IFN- $\gamma$ for the indicated periods of time.

‡ Cells were harvested and washed in PBS. NAD levels were determined as described in Methods. Protein was measured by the Bradford method using bovine serum albumin as a protein standard (51). $\S$ The numbers in parentheses indicate percent of control NAD levels.

(Fig. 5). Inhibitors of IFN- $\gamma$ activity also prevented the loss of intracellular NAD. These data are shown in Table X. ME180 and A549 cells which are protected from IFN- $\gamma$-mediated growth inhibition by tryptophan also did not lose intracellular NAD in the presence of additional tryptophan. Inhibitors of ADP-RT did not prevent the loss of NAD in these cell lines. By contrast, inhibitors of ADP-RT prevented both inhibition of cell growth and loss of intracellular NAD in BT20 and HT29 cell lines whereas addition of tryptophan failed to prevent growth inhibition as well as loss of NAD in these cell lines.

Levels of intracellular ATP were also lower in IFN- $\gamma-$ treated cells. Control ME180 cells had $26 \mathrm{nmol}$ ATP/mg pro-

Table X. Inhibition of IFN- $\gamma-$ mediated Depletion of Intracellular NAD

\begin{tabular}{lccccc}
\hline & & \multicolumn{4}{c}{ NAD $^{\ddagger}$} \\
\cline { 3 - 6 } Cell line* & IFN- $\gamma$ & $\begin{array}{c}\text { No } \\
\text { addition }\end{array}$ & Tryptophan & $\begin{array}{c}\text { 3-Amino- } \\
\text { benzamide }\end{array}$ & Nicotinamide \\
\hline & $U / m l$ & \multicolumn{5}{c}{ nmol/mg protein } \\
ME180 & - & 2.9 & 3.0 & 3.0 & ND \\
& 30 & 0.6 & 2.1 & 0.8 & ND \\
A549 & - & 3.8 & 3.5 & 3.6 & ND \\
& 30 & 1.2 & 3.3 & 1.6 & ND \\
BT20 & - & 3.6 & 3.5 & 3.0 & 3.4 \\
& 300 & 0.6 & 0.6 & 3.4 & 3.5 \\
HT29 & - & 7.3 & 7.1 & 7.3 & 7.4 \\
& 300 & 1.1 & 0.9 & 6.7 & 6.0 \\
& & & & & \\
\hline
\end{tabular}

* Cell lines were cultured in the presence or absence of IFN- $\gamma$ for $2 \mathrm{~d}$ (ME180 and A549) or 4 d (BT20 and HT29).

₹ Cells were harvested and washed in PBS. NAD levels were determined as described in Methods and protein was determined by the Bradford method using bovine serum albumin as a protein standard. ${ }^{\S} \mathrm{ND}$, not determined. tein whereas IFN- $\gamma$-treated cells $(30 \mathrm{U} / \mathrm{ml}, 3 \mathrm{~d}$ ) had $11 \mathrm{nmol}$ ATP/mg protein. Control A549 cells had $46 \mathrm{nmol}$ ATP/mg protein whereas IFN- $\gamma$-treated cells $(100 \mathrm{U} / \mathrm{ml}, 3 \mathrm{~d}) \mathrm{had} 13$ $\mathrm{nmol}$ ATP/mg protein. Control HT29 cells had $25 \mathrm{nmol}$ ATP/mg protein while IFN- $\gamma$-treated HT29 cells $(300 \mathrm{U} / \mathrm{ml}$ IFN- $\gamma, 5 \mathrm{~d}$ ) had $15 \mathrm{nmol}$ ATP/mg protein. Continued incubation of IFN- $\gamma$-treated tumor cell lines resulted in further decreases in ATP levels (data not shown).

The effects of 3-aminobenzamide and nicotinamide on NAD loss and inhibition of cell growth mediated by IFN- $\gamma$ suggest that ADP-RT may be activated by IFN- $\gamma$. As shown in Table XI, ADP-RT activity was increased in BT20 cells and HT2 29 cells by IFN- $\gamma$ by two- to threefold. Addition of $\mathrm{H}_{2} \mathrm{O}_{2}$, a cytotoxic compound previously shown to activate ADP-RT, increased ADP-RT activity by three- to fourfold in these cells. By contrast, ADP-RT activity was not increased in ME180 cells cultured with IFN- $\gamma$. Inhibition of growth of this cell line by IFN- $\gamma$ was not prevented by inhibitors of ADP-RT.

IFN- $\gamma$ induces DNA strand breaks. Activation of ADP-RT has been shown to follow DNA strand breaks caused by a number of cytotoxic agents. As shown in Table XII, IFN- $\gamma$ induced an increase in DNA strand breaks in BT20 cells but not in ME180 or A549 cells. DNA strand breaks began to accumulate in BT2 20 cells after $48 \mathrm{~h}$ with IFN- $\gamma$ and reached maximum levels after $72 \mathrm{~h}$. DNA strand breaks as measured by alkaline elution did not increase further after $72 \mathrm{~h}$ of culture with IFN- $\gamma$ (data not shown).

\section{Discussion}

Factors that govern sensitivity of growth of tumor cells in vitro or in vivo to inhibition by IFN- $\boldsymbol{\gamma}$ are not well understood. Certain tumor cell lines are sensitive to inhibition by IFN- $\gamma$ in vitro but others are relatively or completely resistant to inhibition by IFN- $\gamma$. Certain tumor cell lines sensitive to inhibition by IFN- $\gamma$ in vitro are quite resistant to inhibition by IFN- $\gamma$ in vivo. Further, treatment of cancer with IFN- $\gamma$ has not produced the results that were originally anticipated $(31,32)$. An improved understanding of the mechanisms by which IFN- $\gamma$

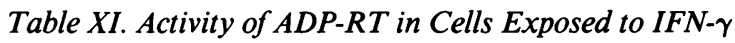

\begin{tabular}{|c|c|c|c|c|}
\hline \multirow[b]{2}{*}{ Cell line* } & \multirow{2}{*}{$\begin{array}{l}\text { Day of } \\
\text { assay }\end{array}$} & \multicolumn{3}{|c|}{ ADP-RT activity ${ }^{*}$} \\
\hline & & $-\mathrm{IFN}-\gamma$ & $+\mathrm{IFN}-\gamma$ & $+1 \mathrm{mM} \mathrm{H}_{2} \mathrm{O}_{2}^{8}$ \\
\hline & & \multicolumn{3}{|c|}{ pmol ADP ribose/min $\cdot m g$ protein } \\
\hline \multirow[t]{2}{*}{ ME180 } & 2 & 47 & 55 & $\mathbf{N D}^{\prime \prime}$ \\
\hline & 4 & 33 & 36 & ND \\
\hline \multirow[t]{3}{*}{ BT20 } & 2 & 42 & 54 & - \\
\hline & 3 & 40 & 98 & 126 \\
\hline & 4 & 38 & 76 & - \\
\hline HT29 & 3 & 44 & 113 & 162 \\
\hline
\end{tabular}

* The tumor cell lines, ME180, BT20, and HT29, were cultured with $300 \mathrm{U} / \mathrm{ml}$ IFN- $\gamma$ for the indicated period of time.

${ }^{\ddagger}$ ADP-RT activity was determined in permeabilized cells as described in Methods.

${ }^{8} \mathrm{H}_{2} \mathrm{O}_{2}$ ( $1 \mathrm{mM}$ final concentration) was added to cells for $30 \mathrm{~min}$ at $37^{\circ} \mathrm{C}$ before assay of ADP-RT activity.

" ND, not determined. 
Table XII. IFN- $\gamma$ Causes DNA Strand Breaks in Tumor Cells

\begin{tabular}{lll}
\hline & \multicolumn{2}{c}{$\begin{array}{c}\text { Fraction of }\left[{ }^{14} \mathrm{C}\right] \text { dThd-labeled } \\
\text { DNA retained on filters relative } \\
\text { to }\left[{ }^{3} \mathrm{H}\right] \mathrm{dTh} \text { Th-labeled DNA }\end{array}$} \\
\cline { 2 - 3 } Cell line & $-\mathrm{IFN}-\gamma$ & $+\mathrm{IFN}-\gamma$ \\
\hline ME180* & $0.90^{\ddagger}$ & 0.94 \\
A549 & 0.95 & 0.89 \\
BT20 & 0.97 & 0.61
\end{tabular}

* ME180, A549, or BT20 cells were cultured for $3 \mathrm{~d}$ in the absence or presence of $300 \mathrm{U} / \mathrm{ml}$ IFN- $\gamma$.

${ }^{\ddagger}$ Alkaline elution of $\left[{ }^{14} \mathrm{C}\right] \mathrm{dTh}$ Th-labeled DNA was determined as described in Methods.

inhibits tumor cell growth and identification of the factors that govern the response of tumor cells to IFN- $\gamma$ may help explain sensitivity or resistance of growth of tumor cells under different conditions.

Most tissue culture experiments are performed in $5 \% \mathrm{CO}_{2}$ in air which is $20 \% \mathrm{O}_{2}$ whereas the concentration of oxygen in interstitial fluid in tissue is $\sim 4 \%$ (33). Activity of IFN- $\gamma$ against all tumor cell lines tested was significantly reduced by decreasing oxygen concentration. By contrast, inhibition of cell division (ME180) by TNF- $\alpha$ was unaffected by low oxygen concentration. The synergistic antiproliferative activity of TNF- $\alpha$ and IFN- $\gamma$ against BT2 20 cells was also inhibited by reducing oxygen concentration $(15 \%$ of control cell growth with $10 \mathrm{U} / \mathrm{ml} \mathrm{TNF}-\alpha$ plus $30 \mathrm{U} / \mathrm{ml} \mathrm{IFN}-\gamma$ in the presence of $20 \%$ oxygen vs. $45 \%$ of control cell growth or $70 \%$ of control cell growth in the presence of $12 \%$ or $4 \%$ oxygen, respectively). Reduced oxygen tension also slowed the growth rate of these tumor cells. Thus it is possible that the reduced effect of IFN- $\gamma$ is simply associated with the reduced growth rate. However, the response of ME1 80 cells to TNF- $\alpha$ was unaffected by reduced oxygen tension even in the presence of a slower growth rate. Further, a variety of agents such as TNF- $\alpha$, actinomycin $\mathrm{D}$, or cycloheximide, which slow the growth rates of certain mammalian cells, enhance rather than reduce the ability of IFN- $\gamma$ to inhibit cell growth. This supports the notion that the reduced effectiveness of IFN- $\gamma$ in the presence of lower oxygen tension may be relatively specific. The results discussed below point to specific mechanisms of IFN- $\gamma$-mediated inhibition of cell growth which may require reduced species of molecular oxygen.

High concentrations of molecular oxygen are relatively toxic to cells (34). Certain agents that inhibit cell growth appear to do so by generating reactive species or free radicals of oxygen $(35,36)$. It has been demonstrated that intracellular concentrations of reduced glutathione play an important role in the protection of cells to oxidizing or ionizing species. Raising or lowering glutathione levels decrease or increase sensitivity of cells to a variety of agents including peroxide, activated macrophages or granulocytes, ionizing radiation, elevated temperatures, ethanol, and several antineoplastic agents (37). Sensitivity of tumor cells to inhibition by IFN- $\gamma$ was also increased or decreased by reducing or increasing intracellular glutathione concentrations, respectively. There was no correlation, however, between intracellular glutathione content and sensitivity of cells to IFN- $\gamma$. In fact, those cell lines which were most sensitive to IFN- $\gamma$ contained the highest concentration of glutathione (data not shown). By contrast, sensitivity of various tumor cell lines to the oxidative cytolysis by peroxide or by macrophages or granulocytes is proportional to decreased intracellular glutathione content (28).

Catalase and superoxide dismutase have also been implicated in the cellular defense mechanism against oxidizing species. The tumor cell lines employed in these studies had similar concentrations of catalase $(2.2-3.0 \mathrm{U} / \mathrm{mg}$ protein) and undetectable amounts of superoxide dismutase (38). The concentration of catalase in these tumor cell lines is significantly less than that found in other tissues such as liver $(330 \mathrm{U} / \mathrm{mg}$ protein) or erythrocytes which have relatively high concentrations of catalase. It is possible that these enzymes may contribute less to the defense mechanism of these tumor cells against oxygen toxicity than does the level of reduced glutathione.

Alteration in the sensitivity of tumor cell lines to inhibition by IFN- $\gamma$ by changing oxygen concentration or glutathione concentration is consistent with the notion that IFN- $\gamma$ may inhibit tumor cell growth through an oxidative mechanism. Two mechanisms were identified and both have an oxidative basis. Results presented here as well as elsewhere $(8,9)$ suggest that IFN- $\gamma$ stimulates certain tumor cell lines to consume or catabolize tryptophan in media and produce kynurenine, a product of tryptophan oxidation. Loss of tryptophan from media preceded the loss in intracellular NAD levels and preceded the inhibitory effects of IFN- $\gamma$ on cell growth by $\sim 24 \mathrm{~h}$ in A549 and ME180 cells. Two enzymes that catalyze the oxidative decyclization of L-tryptophan have been described; these are tryptophan 2,3-dioxygenase and indoleamine 2,3dioxygenase (13). Both of these enzymes require superoxide anion for activity $(39,40)$. Induction of indoleamine 2,3-dioxygenase by IFN- $\gamma$ has been observed in various tissues or cell types (41). Addition of exogenous tryptophan has also been shown to prevent the ability of IFN- $\gamma$ to cause inhibition of the intracellular replication of certain pathogens. This includes the intracellular replication of the protozoan Toxoplasma gondii in human fibroblasts (3) and the replication of Chlamydia psittaci in T24 human bladder carcinoma cell lines (42). Addition of exogenous tryptophan does not overcome the block in replication of Rickettsia prowazekii by IFN- $\gamma$ in human cells or of Chlamydia trachomatis in murine cells $(10,43)$. One mechanism to account for inhibition of replication of either certain tumor cell lines or certain intracellular pathogens by IFN- $\gamma$ may be the induction of host indoleamine 2,3-dioxygenase activity. It is clear from these data that an additional mechanism exists to account for the inhibitory activity in cells not protected by addition of tryptophan. This is in contrast to previous reports where it was suggested that induction of tryptophan oxidation by cells exposed to IFN- $\gamma$ may be a universal phenomenon in human tissue (8). It is consistent with the fact that certain tumor cell lines have increased indoleamine 2,3dioxygenase activity and increase rates of superoxide anion release after treatment with IFN- $\gamma$ whereas other tumor cell lines do not (9). Major differences in the rate of transport of individual amino acids appear not to exist in mammalian cells. After culture with IFN- $\gamma$, the initial rate of transport of tryptophan is unchanged but the uptake and oxidation of tryptophan over longer periods of time is increased dramatically in various mammalian cells (3, unpublished observations). The rate of transport as well as the rate of degradation of 
various other amino acids appear not to be affected by IFN- $\gamma$ in mammalian cells.

A second mechanism to account for inhibition of tumor cell growth by IFN- $\gamma$ was activation of ADP-RT and depletion of intracellülar NAD. Inhibitors of ADP-RT, 3-aminobenzamide and nicotinamide (29), blocked IFN- $\gamma$-mediated depletion of NAD and inhibition of growth of BT20, HT29, and SKLU1 cells. The number of DNA strand breaks was also increased after culture with IFN- $\gamma$. DNA strand breaks have been shown to activate ADP-RT and activation of ADP-RT has been shown to result in depletion of NAD and cellular toxicity (44). Direct addition of large amounts of $\mathrm{H}_{2} \mathrm{O}_{2}$ has been shown to rapidly induce DNA strand breaks and lead to activation of ADP-RT, depletion of NAD, and cell death (14). Similar mechanisms have been proposed to account for the lymphocyte toxicity of deoxyadenosine and 2-chlorodeoxyadenosine (19). A wide variety of oxidizing species or systems known to generate oxidizing species induce DNA strand breaks. Activation of ADP-RT by DNA strand breaks appears to be an important mechanism to account for the cellular toxicity of oxidizing species. IFN- $\gamma$ did not stimulate production of either $\mathrm{H}_{2} \mathrm{O}_{2}$ or $\mathrm{O}_{2}^{-}$in those cell lines which had increased DNA strand breaks or increased activity of ADP-RT. However, catalase, an enzyme that decomposes $\mathrm{H}_{2} \mathrm{O}_{2}$, partially prevented IFN- $\gamma$-mediated inhibition of growth by these cell lines (BT20 and HT29) but not of other IFN- $\gamma$-sensitive cell lines (ME180 and A549). The precise mechanism by which IFN- $\gamma$ stimulates an increase in DNA strand breaks is presently unknown.

Intracellular depletion of NAD was observed in both classes (tryptophan depletion and ADP-RT activation) of tumor cells after treatment with IFN- $\gamma$. Inhibitors of ADP-RT activity did not block IFN- $\gamma$-mediated loss of NAD or cellular toxicity in those cell lines (ME180 and A549) stimulated by IFN- $\gamma$ to catabolize tryptophan. Addition of tryptophan, however, prevented both the loss of intracellular NAD as well as inhibition of cell division caused by IFN- $\gamma$ in these cell lines. Inhibitors of ADP-RT activity did block both the loss of intracellular NAD and cellular toxicity associated with activation of ADP-RT. In these cell lines (BT20 and HT29) addition of tryptophan did not prevent loss of intracellular NAD or cellular toxicity mediated by IFN- $\gamma$.

NAD primarily exists in the oxidized form within tissues and eukaryotic cells. Since the method for extraction of NAD employed in these studies does not preserve NADH, it is possible that some of the observed decrease in NAD could result from a shift from the oxidized to the reduced pool of NAD. Results presented here suggest that depletion of intracellular NAD represents a common denominator of IFN- $\gamma$-mediated inhibition of tumor cell growth. Intracellular levels of ATP also fell after culture of tumor cells with IFN- $\gamma$. Depletion of ATP after DNA damage has been shown to be secondary to depletion of NAD (45). Thus the fall in NAD may result in inhibition of glycolysis as well. Additionally, depletion of NAD through the formation of protein-bound ADP-ribose may result in the depletion of ATP through synthesis of NAD from nicotinamide mononucleotide (14).

Activity of ADP-RT is also involved in cellular differentiation and inhibitors of ADP-RT inhibit myoblast differentiation and the expression of fetal functions by adult hepatocytes in tissue culture $(46,47)$. Inhibitors of ADP-RT also prevent mitogen-induced activation and proliferation of human lym- phocytes (48). The activity of this enzyme must be well regulated if its activation can lead to loss of cell viability in one instance and the expression of differentiated function without loss of cell viability in another instance. It is interesting to note that IFN- $\gamma$ has been shown to cause inhibition of cell growth and loss of viability of certain tumor cell lines in some instances and also to stimulate the expression of differentiated functions by other cell types in the absence of loss of cell viability (2).

It is unclear whether increases in oxygen concentration or decreases in intracellular glutathione content will alter the activity of IFN- $\gamma$ against tumor cells in vivo. Humans or animals excrete tryptophan oxidation products such as kynurenine after administration of IFN- $\gamma(49,50)$. This indicates that IFN- $\gamma$ can have similar effects on cells in vivo and in vitro. At this point, it is not certain whether administration of IFN- $\gamma$ in vivo stimulates tumor cells to catabolize tryptophan in vivo or to activate ADP-RT and deplete intracellular NAD in vivo. By measuring tryptophan catabolism, DNA strand breaks, intracellular NAD.depletion, induction of indoleamine 2,3-dioxygenase, or activation of ADP-RT in tumor cells or tumor cell tissue after administration of IFN- $\gamma$ in vivo, it may be possible to further our understanding of the differences between the antitumor activity of IFN- $\gamma$ in vitro and in vivo.

Finally, experiments presented here as well as elsewhere (8, 9) suggest that there may be a fundamental difference between the way nontransformed and transformed cell lines respond to IFN- $\gamma$. Both normal and transformed cells can respond to IFN- $\gamma$ by increasing levels of indoleamine 2,3-dioxygenase. However, transformed cells also respond by lowering levels of intracellular NAD and inhibiting cell growth. By contrast, the normal diploid lung fibroblast line, MRC5, does not lose intracellular NAD or slow its growth rate in the presence of NAD even though the media is depleted of tryptophan. Therefore, nontransformed and transformed cells may differ in their requirements for tryptophan. This appears to be the case. The half-maximal growth rate of normal lung diploid cells (MRC5 and IMR90) or mitogen-activated human peripheral blood lymphocytes is obtained with $3 \mu \mathrm{M}$ tryptophan (range of 2-5 $\mu \mathrm{M})$ and the half-maximal growth rate of several human tumor cell lines (ME180, A549, HT29, SKLU1, SKC01, or BT20) is obtained with $36 \mu \mathrm{M}$ (range of $25-50 \mu \mathrm{M}$ ). This difference may be unique to tryptophan. The change in the growth rates of these same normal and transformed cell lines is similar in the presence of varying concentrations of methionine or leucine, two other essential amino acids. This may be important when considering the properties of normal and transformed cells.

\section{Acknowledgments}

We thank Edward P. Amento for helpful discussions and the review of this manuscript, Glenn C. Rice for measuring intracellular glutathione concentrations, Cindy Hoy for measuring DNA strand breaks, Donna Eastman and Byron Nelson for measuring tryptophan and kynurenine concentrations in media, and Socorro Cuisia for her assistance in preparing the manuscript.

\section{References}

1. Stewart, W. E. II. 1979. The Interferon System. Springer-Verlag, New York. 1-136. 
2. Vilcek, J., P. W. Gray, E. Rinderknecht, and C. G. Sevastopoulos. 1985. Interferon- $\gamma$ : a lymphokine for all seasons. Lymphokines. 11:1-32.

3. Pfefferkorn, E. R. 1984. Interferon- $\gamma$ blocks the growth of Toxoplasma gondii in human fibroblasts by inducing the host cells to degrade tryptophan. Proc. Natl. Acad. Sci. USA. 81:908-912.

4. Denz, H., M. Lechleitner, C. Marth, G. Daxenbichler, and H. Braunsteiner. 1985. Effect of human recombinant alpha-2 and gamma interferon on the growth of human cell lines from solid tumors and hematologic malignancies. J. Interferon Res. 5:147-157.

5. Lengyel, P. 1981. Enzymology of interferon action: a short survey. Methods Enzymol. 79:135-148.

6. Pfeffer, L. M., E. Wang, F. R. Landsberger, and I. Tamm. 1981. Assays to measure plasma membrane and cytoskeletal changes in interferon-treated cells. Methods Enzymol. 79:461-493.

7. Talmadge, J. E., H. R. Tribble, R. W. Pennington, H. Phillips, and R. H. Wiltrout. 1987. Immunomodulatory and immunotherapeutic properties of recombinant gamma interferon and recombinant tumor necrosis factor in mice. Cancer Res. 47:2470-2563.

8. de La Maza, L. M., and E. M. Peterson. 1988. Dependence of the in vitro antiproliferative activity of recombinant human $\gamma$-interferon on the concentration of tryptophan in culture media. Cancer Res. 48:346-350.

9. Ozaki, Y., M. P. Edelstein, and D. S., Duch. 1988. Induction of indoleamine 2,3-dioxygenase: A mechanism of the antitumor activity of interferon- $\gamma$. Proc. Natl. Acad. Sci. USA. 85:1242-1246.

10. De La Maza, L. M., E. M. Peterson, C. W. Fennie, and C. W. Czarniecki. 1985. The anti-chlamydial and anti-proliferative activities of recombinant murine interferon-gamma are not dependent on tryptophan concentrations. J. Immunol. 135:4198-4200.

11. Folkman, J. 1974. Tumor angiogenesis. Adv. Cancer Res. 19:331-358.

12. Ueda, K., and O. Hayaishi. 1985. ADP-ribosylation. Annu. Rev. Biochem. 54:73-100.

13. Yoshia, R., and O. Hayaishi. 1984. Overview: superoxygenase. Methods Enzymol. 105:61-70.

14. Schraufstatter, D. B., P. A. Hyslop, R. G. Spragg, and C. G. Cochrane. 1986. Oxidant injury of cells: DNA strand-breaks activate polyadenosine diphosphate-ribose polymerase and lead to depletion of nicotinamide adenine dinucleotide. J. Clin. Invest. 77:1312-1320.

15. Familletti, P. C., S. Rubinstein, and S. Pestka. 1981. A convenient and rapid cytopathic effect inhibition assay for interferon. Methods Enzymol. 78:387-394.

16. Jones, B. N., and J. P. Gilligan. 1983. $o$-Phthaldialdehyde precolumn derivatization and reversed phase high performance liquid chromatography of polypeptide hydrolysates and physiological fluids. J. Chromatogr. 266:471-482.

17. Meister, A. 1983. Selective modification of glutathione metabolism. Science (Wash. DC). 220:472-477.

18. Rice, G. C., E. A. Bump, D. C. Shrieve, W. Lee, and M. Kovacs. 1986. Quantitative analysis of cellular glutathione by flow cytometry utilizing monochlorobimane: Some application to radiation and drug resistance in vitro and in vivo. Cancer Res. 46:6105-6110.

19. Seto, S., C. J. Carrera, M. Kubota, D. B. Wasson, and D. A. Carson. 1985. Mechanism of deoxyadenosine and 2-chlorodeoxyadenosine toxicity to nondividing lymphocytes. J. Clin. Invest. 75:377-383.

20. Clifford, D. P., and J. E. Repine. 1984. Measurement of oxidizing radicals by polymorphonuclear leukocytes. Methods Enzymol. 105:393-398.

21. de la Harpe, J., and C. F. Nathan. 1985. A semi-automated micro-assay for $\mathrm{H}_{2} \mathrm{O}_{2}$ release by human blood monocytes and mouse peritoneal macrophages. J. Immunol. Meth. 78:323-336.

22. Althaus, F. R., S. D. Lawrence, G. L. Sattler, and H. C. Pitot. 1982. ADP-ribosyl transferase activity in cultured hepatocytes: interactions with DNA repair. J. Biol. Chem. 257:5528-5535.

23. Fiskum, G., S. W. Craig, G. L. Decker, and A. L. Lehninger.
1980. The cytoskeleton of digitonin-treated rat hepatocytes. Proc. Natl. Acad. Sci. USA. 77(6):3430-3434.

24. Aebi, H. 1984. Catalase in vitro. Methods Enzymol. 105:121126.

25. Flohe, L., and F. Otting. 1984. Superoxide dismutase assays. Methods Enzymol. 105:93-104.

26. Kohn, K. W., L. C. Erickson, R. A. G. Ewis, and C. A. Friedman. 1976. Fractionation of DNA from mamalian cells by alkaline elution. Biochemistry. 15:4629-4637.

27. Siedlik, P. H., and L. J. Marnett. 1984. Oxidizing radical generation by prostaglandin H synthetase. Methods Enzymol. 105:412-416.

28. Arrick, B. A., C. F. Nathan, O. W. Griffith, and Z. A. Cohn. 1982. Glutathione depletion sensitizes tumor cells to oxidative cytolysis. J. Biol. Chem. 257:1231-1237.

29. Sims, J. L., G. W. Sikorski, D. M. Catino, S. J. Berga, and N. A. Berger. 1982. Poly(adenosine diphosphorylase) polymerase inhibitors stimulate unscheduled deoxyribonucleic acid synthesis in normal human lymphocytes. Biochemistry. 21:1813-1821.

30. Gaal, J. C., K. R. Smith, and C. K. Pearson. 1987. Cellular euthanasia mediated by a nuclear enzyme: a central role for nuclear ADP-ribosylation in cellular metabolism. Trends Biochem. Sci. 12:129-130.

31. van der Burg, M., M. Edelstein, L. Gerlis, C. M. Liang, M. Hirschi, and A. Dawson. 1985. Recombinant interferon-gamma (Immuneron): results of a phase I trial in patients with cancer. J. Biol. Response Modif. 4:264-272.

32. Rinehart, J. J., L. Malspeis, D. Young and J. A. Neidhart. 1986. Phase I-II trial of human recombinant interferon-gamma in renal cell carcinoma. J. Biol. Response Modif. 5:300-308.

33. Knighton, D. R., T. K. Hunt, H. Scheuenstuhl, B. J. Halliday, Z. Werb, and M. J. Bande. 1983. Oxygen tension regulates the expression of angiogenesis factor by macrophages. Science (Wash. DC). 221:1283-1285.

34. McCord, J. M., B. B. Keele, Jr., and I. Fridvich. 1971. An enzyme-based theory of obligate anaerobiosis: The physiological function of superoxide dismutase. Proc. Natl. Acad. Sci. USA. 68:10241027.

35. Kuthan, H., H. Tsuji, H. Graf, V. Ullrich, J. Werringloer, and R. W. Estabrook. 1978. Generation of superoxide anion as a source of hydrogen peroxide in a reconstituted monooxygenase system. FEBS (Fed. Eur. Biochem. Soc.) Lett. 91:343-345.

36. Jones, D. P., H. Thor, B. Anderson, and S. Orrenius. 1978. Detoxification reactions in isolated hepatocytes; role of glutathione peroxidase, catalase and formaldehyde dehydrogenase in reactions relating to $N$-dimethylation by the cytochrome P-450 system. J. Biol. Chem. 253:6031-6037.

37. Arrick, B. A., and C. F. Nathan. 1984. Glutathione metabolism as a determinant of therapeutic efficacy: a review. Cancer Res. 44:4224-4232.

38. Wong, G. H. W., and D. V. Goeddel. 1988. Induction of Mnsuperoxide dismutase by tumor necrosis factor: possible protective mechanism. Science (Wash. DC). 242:941-944.

39. Hirata, F., and O. Hayaishi. 1971. Possible participation of superoxide anion in the intestinal tryptophan 2,3-dioxygenase reaction. J. Biol. Chem. 246:7825-7826.

40. Taniguchi, T., F. Hirata, and O. Hayaishi. 1977. Intracellular utilization of superoxide anion by indoleamine 2,3-dioxygenase of rabbit enterocytes. J. Biol. Chem. 252:2774-2775.

41. Yoshida, R., J. Imanishi, T. Oku, T. Kishida, and O. Hayaishi. 1981. Induction of pulmonary indoleamine 2,3-dioxygenase by interferon. Proc. Natl. Acad. Sci. USA. 78:129-132.

42. Byrne, G. I., L. K. Lehmann, and G. J. Landry. 1986. Induction of tryptophan catabolism is the mechanism for gamma-interferonmediated inhibition of intracellular Chlamydia psittaci replication in T24 cells. Infect. Immun. 53:347-351.

43. Turco, J., and H. H. Winkler. 1986. Gamma-interferon-in- 
duced inhibition of the growth of Rickettsia prowazekii in fibroblasts cannot be explained by the degradation of tryptophan or other amino acids. Infect. Immun. 53:38-46.

44. Berger, N. A. 1985. Symposium: cellular response to DNA damage: the role of poly (ADP-ribose). Radiat. Res. 101:4015.

45. Berger, S. J., D. C. Sudar, and N. A. Berger. 1986. Metabolic consequences of DNA damage: DNA damage induces alterations in glucose metabolism by activation of poly (ADP-ribose) polymerase. Biochem. Biophys. Res. Commun. 134:227-232.

46. Farzaneh, F., R. Zolin, D. Brill, and S. Shall. 1982. DNA strand breaks and ADP-ribosyl transferase activation during cell differentiation. Nature (Lond.). 300:362-366.

47. Althaus, F. R., S. D. Lawrence, Y.-Z. He, G. L. Sattler, Y. Tsakada, and H. C. Pitot. 1982. Effects of altered [ADP-ribose] ${ }_{n}$ me- tabolism on expression of fetal functions by adult hepatocytes. Nature (Lond.). 300:366-368.

48. Johnstone, A. P., and G. T. Williams. 1982. Role of DNA breaks and ADP-ribosyl transferase activity in eukaryotic differentiation demonstrated in human lymphocytes. Nature (Lond.). 300:368370.

49. Borden, E. C., I. B. Rosenzweig, and G. I. Byrne. 1987. Interferons: from virus inhibitor to modulator of amino acid and lipid metabolism. J. Interferon Res. 7:591-596.

50. Byrne, G., L. K. Lehmann, J. G. Kirschbaum, E. C. Borden, C. M. Lee, and R. R. Brown. 1986. Induction of tryptophan degradation in vitro and in vivo: a gamma interferon stimulated activity. $J$. Interferon Res. 6:389-398.

51. Bradford, M. 1976. A rapid and sensitive method for the quantitation of microgram quantities of protein utilizing the principle of protein-dye binding. Anal. Biochem. 72:248-254. 